\author{
Marquette University \\ e-Publications@Marquette
}

School of Dentistry Faculty Research and

Publications

Dentistry, School of

3-22-2019

\title{
The effectiveness of different attachment systems maxillary and mandibular implant overdentures
}

Gary L. Stafford

Follow this and additional works at: https://epublications.marquette.edu/dentistry_fac

Part of the Dentistry Commons 
Marquette University

e-Publications@Marquette

\section{Dentistry Faculty Research and Publications/School of Dentistry}

This paper is NOT THE PUBLISHED VERSION; but the author's final, peer-reviewed manuscript. The published version may be accessed by following the link in the citation below.

Evidence-Based Dentistry, Vol. 20, No. x (March 22 2019): 26-27. DOI. This article is (C) Nature Publishing Group and permission has been granted for this version to appear in $\underline{\mathrm{e}}-$ Publications@Marquette. Nature Publishing Group does not grant permission for this article to be further copied/distributed or hosted elsewhere without the express permission from Nature Publishing Group.

\section{The effectiveness of different attachment systems maxillary and mandibular implant overdentures}

Gary L. Stafford: Department of General Dental Sciences, Marquette University School of Dentistry, Milwaukee, Wisconsin

\section{Abstract}

Data sources Cochrane Oral Health's Trials Register, the Cochrane Central Register of Controlled Trials (CENTRAL), Medline, Embase, the US National Institutes of Health Ongoing Trials Register (ClinicalTrials.gov) and the World Health Organization International Clinical Trials Registry Platform.

Study selection Randomised controlled trials (RCTs), including cross-over trials on maxillary or mandibular implant overdentures with different attachment systems with at least one-year follow-up were considered. There were no restrictions on language or date of publication.

Data extraction and synthesis Data were abstracted by four reviewers with risk of bias being assessed using the Cochrane tool. Data were combined using a fixed effects meta-analysis. The GRADE approach was used to assess the overall body of evidence. 
Results Six RCTs with a total of 294 mandibular overdentures were included. All of the trials were considered to be at high risk of bias. No studies on maxillary overdentures were included. For bar and ball attachments there was low quality evidence [two studies] that short-term re-treatment (repair of attachment system) was higher with ball attachments; $\mathrm{RR}=3.11(95 \% \mathrm{Cl} ; 1.68$ to 5.75$)$ but no difference $\mathrm{RR}=1.18(95 \% \mathrm{Cl} ; 0.38$ to 3.71$)$ for replacements of attachment systems. There was no difference between ball and magnet systems in mediumterm prosthodontic success or repair of attachment systems, but prosthodontic maintenance costs were higher when magnet attachments were used [one study - very low quality evidence]. Only one trial compared ball and telescopic attachments providing very low quality evidence.

Conclusions For mandibular overdentures, there is insufficient evidence to determine the relative effectiveness of different attachment systems on prosthodontic success, prosthodontic maintenance, patient satisfaction, patient preference or costs. No trial evidence was available for maxillary overdentures.

\section{A Commentary on}

Payne AG, Alsabeeha NH, Atieh MA, Esposito M, Ma S, Anas El-Wegoud M.

Interventions for replacing missing teeth: attachment systems for implant overdentures in edentulous jaws. Cochrane Database Syst Rev2018 10: Art. No.: CD008001. DOI: 10.1002/14651858.CD008001.pub2.
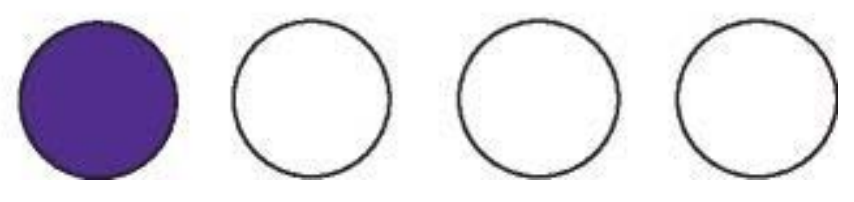

GRADE rating

Cochrane Reviews are regularly updated as new evidence emerges and in response to feedback, the Cochrane Library (www.thecochranelibrary.com) should be consulted for the most recent version of the review.

\section{Commentary}

The significance of dental implant attachment systems for the edentulous patient was initially established in the 2002 McGill consensus statement on overdentures which concluded that the treatment of choice for an edentulous mandible should be a two-implant retained overdenture.1 Subsequent to that landmark statement, the 2008 York consensus statement on implant-supported overdentures concluded that patients' satisfaction and quality of life with implant retained mandibular overdentures is significantly better than with conventional dentures. $\underline{2}$

Given that implant overdentures are the de facto standard of care and are increasingly utilised in the rehabilitation of the edentulous patient, the authors of this Cochrane Review chose to compare different attachment systems for both maxillary and mandibular implant overdentures. Their purpose was to assess the degree of prosthodontic success, prosthodontic maintenance, patient preference, patient satisfaction, quality of life, and costs of dental implant overdenture attachment systems. They deemed that it was important to perform this review since the design of the chosen attachment and the decision by the clinician on the number of implants to be placed would theoretically have a direct impact on each of these individual aims.

This Cochrane intervention review clearly described the rigorous inclusion/exclusion criteria necessary for articles to meet the study's eligibility requirements. Following an extensive independent search that was designed to be sensitive for randomised controlled clinical trials, the four authors identified six trials that included a total of 294 mandibular overdentures. Unfortunately, the authors were unable to identify any eligible 
trials for maxillary implant overdentures and thus no conclusions could be drawn for implant overdentures in the maxillary arch. This would indicate, as noted in the review, that there is a great need for further research in this area.

There are a variety of implant retention systems which can be utilised to retain an implant overdenture, but in general, implant attachment systems are made up of just two parts; one part connected to the implant directly or via a bar, and the other within the prosthesis. $\underline{3}$ In total, these selected studies evaluated each of the four broad categories of retentive mechanisms for implant overdentures; ball/stud, bar, magnetic and telescopic. Notably, the chosen randomised controlled trials (RCTs) researched these different attachment styles on the same implant system.

Among the many positive aspects of this review was the fact that the authors used the GRADE approach to assess the quality of the evidence. GRADE offers a transparent and structured process for developing and presenting evidence summaries and for carrying out the steps involved in making recommendations. $\underline{\text { In }}$ this intervention review, the authors deemed the quality of evidence to be very low, partly due to the relatively few participants and events in the included studies. They also concluded that there were serious limitations in the trial designs with data missing or not all outcomes being reported. Given these shortcomings, the results of this intervention review did not lead to definitive answers for the stated objectives nor was it possible to make a recommendation for a preferred attachment system for implant overdentures in edentulous jaws.

\section{Practice points}

- There is insufficient evidence to determine any significant differences between mandibular implant denture attachment systems and there is an absence of evidence to draw any definitive conclusions for maxillary implant denture attachment systems

- For mandibular implant overdentures, a preferred attachment system related to the stated objectives of prosthodontic success, prosthodontic maintenance, patient preference and costs could not be identified

- Regardless of the attachment system used for mandibular implant overdentures, improved patient satisfaction should be considered predictable.

\section{References}

1. Thomason JM. he McGill consensus statement on overdentures.Mandibular 2-implant overdentures as first choice standard of care for edentulous patients. Eur J Prosthodont Restor Dent 2002; 10: 95-96.

2. British Society for the Study of Prosthetic Dentistry. The York consensus statement on implant-supported overdentures. Eur J Prosthodont Restor Dent 2009; 17: 164-165.

3. Laverty DP, Green D, Marrison D, Addy L, Thomas MB. Implant retention systems for implant-retained overdentures. Br Dent J 2017; 222: 347-359.

4. Schünemann HJ, Brožek J, Guyatt G, Oxman AD, editor(s). Handbook for grading the quality of evidence and the strength of recommendations using the GRADE approach (updated October 2013). GRADE Working Group, 2013. Available at gdt.guidelinedevelopment.org/app/handbook/handbook.html (accessed February 2019). 